\title{
Neuroprotective effects of hydrogen sulfide on sodium azide-induced autophagic cell death in PC12 cells
}

\author{
HAIYAN SHAN ${ }^{1,2^{*}}$, YANG CHU ${ }^{3 *}$, PAN CHANG $^{4 *}$, LIJUN YANG $^{3}$, YI WANG $^{3}$, \\ SHAOHUA ZHU ${ }^{3}$, MINGYANG ZHANG ${ }^{1,3}$ and LUYANG TAO ${ }^{3}$ \\ ${ }^{1}$ Shanghai Key Laboratory of Forensic Medicine, Institute of Forensic Science, Ministry of Justice, Shanghai 200063; \\ ${ }^{2}$ Department of Obstetrics and Gynecology, North of Suzhou Municipal Hospital, Suzhou, Jiangsu 215008; \\ ${ }^{3}$ Institute of Forensic Sciences, Soochow University, Suzhou, Jiangsu 215123; ${ }^{4}$ Central Laboratory, \\ Second Affiliated Hospital of Xi'an Medical College, Xi'an, Shaanxi 710038, P.R. China
}

Received October 1, 2016; Accepted May 26, 2017

DOI: $10.3892 / \mathrm{mmr} .2017 .7363$

\begin{abstract}
Sodium azide $\left(\mathrm{NaN}_{3}\right)$ is a chemical of rapidly growing commercial importance. It is very acutely toxic and inhibits cytochrome oxidase (COX) by binding irreversibly to the heme cofactor. A previous study from our group demonstrated that hydrogen sulfide $\left(\mathrm{H}_{2} \mathrm{~S}\right)$, the third endogenous gaseous mediator identified, had protective effects against neuronal damage induced by traumatic brain injury (TBI). It is well-known that TBI can reduce the activity of COX and have detrimental effects on the central nervous system metabolism. Therefore, in the present study, it was hypothesized that $\mathrm{H}_{2} \mathrm{~S}$ may provide neuroprotection against $\mathrm{NaN}_{3}$ toxicity. The current results revealed that $\mathrm{NaN}_{3}$ treatment induced non-apoptotic cell death, namely autophagic cell death, in $\mathrm{PC} 12$ cells. Expression of the endogenous $\mathrm{H}_{2} \mathrm{~S}$-producing enzymes, cystathionine- $\beta$-synthase and 3 -mercaptopyruvate sulfurtransferase, decreased in a dose-dependent manner following $\mathrm{NaN}_{3}$ treatment. Pretreatment with $\mathrm{H}_{2} \mathrm{~S}$ markedly attenuated the $\mathrm{NaN}_{3}$-induced cell viability loss and autophagic cell death in a dose-dependent manner. The present study suggests that $\mathrm{H}_{2} \mathrm{~S}$-based strategies may have future potential in the prevention and/or therapy of neuronal damage following $\mathrm{NaN}_{3}$ exposure.
\end{abstract}

\section{Introduction}

Traumatic brain injury (TBI), a form of acquired brain injury, is one of the leading causes of death in children and adults

Correspondence to: Dr Mingyang Zhang or Dr Luyang Tao, Institute of Forensic Sciences, Soochow University, 178 Ganjiang East Road, Suzhou, Jiangsu 215123, P.R. China

E-mail: mingyangzhang@suda.edu.cn

E-mail: taoluyang@suda.edu.cn

*Contributed equally

Key words: hydrogen sulfide, sodium azide, autophagic cell death worldwide. It causes long-term disability with a broad spectrum of symptoms, including headache, confusion, dizziness, blurred vision or tired eyes, ringing in the ears, bad taste in the mouth, fatigue or lethargy, a change in sleep patterns, behavioral or mood changes, and trouble with memory, concentration, attention, or thinking (1). TBI is documented to have detrimental effects on the central nervous system (CNS) metabolism, including the depression of mitochondrial oxidative phosphorylation. Studies have also provided evidence that TBI can suppress the activity of the cytochrome oxidase (COX) and inhibition of COX is an important aspect of trauma pathology (2-4).

Sodium azide $\left(\mathrm{NaN}_{3}\right)$ is a colorless, explosive, and highly toxic salt that is soluble in water. Its principal toxic action is in inhibiting the function of COX in the mitochondrial electron transport chain (5). The tissue-specific inhibition of COX by $\mathrm{NaN}_{3}$ could serve as a useful research tool for the evaluation of cell death in vivo and in vitro. A growing body of evidence suggests that neuronal cell death serves a pivotal role in the TBI process (6-8). Autophagy is known as one of the critical cellular homeostatic mechanisms. Dysregulation of autophagy contributes to neuronal cell death following TBI (9). Previous studies from our group have demonstrated that autophagic cell death could be induced by TBI and therefore, this pathway may serve as a target for future treatments $(10,11)$. Another study has reported that $\mathrm{NaN}_{3}$ could lead to apoptosis in primary cortical neuronal cells (12). Evidence is accumulating that non-apoptotic cell death is associated with neuronal damage induced by $\mathrm{NaN}_{3}$ in primary cortical neuron cultures (13). However, whether $\mathrm{NaN}_{3}$ may induce autophagic cell death remains poorly understood.

Research into the biology of hydrogen sulfide $\left(\mathrm{H}_{2} \mathrm{~S}\right)$ over the last decade has exponentially increased our understanding of the way in which this gasotransmitter influences physiological and pathophysiological processes in a wide range of biological systems (14). $\mathrm{H}_{2} \mathrm{~S}$ has long been hypothesized to be an environmental pollutant which is a colorless, flammable, water-soluble gas characterized by a peculiar smell of rotten eggs (15). $\mathrm{H}_{2} \mathrm{~S}$ is also produced endogenously in mammals, including humans. In particular, cystathionine- $\beta$-synthase (CBS) in the central nervous system and cystathionine- $\gamma$-lyase (CSE) in the 
cardiovascular system are the key enzymes mostly responsible for the endogenous generation of $\mathrm{H}_{2} \mathrm{~S}$ (16). 3-mercaptopyruvate sulfurtransferase (3-MST) is also known to be a significant producer of endogenous $\mathrm{H}_{2} \mathrm{~S}$ in the brain (17). $\mathrm{H}_{2} \mathrm{~S}$ has recently been regarded as a novel gasotransmitter, possessing very important physiological and pharmacological functions in the brain: enhancing $\mathrm{N}$-methyl-D-aspartate receptor-mediated responses, facilitating the induction of hippocampal long-term potentiation, and inhibiting synaptic transmission in the hippocampus $(16,18)$. However, it is not known whether $\mathrm{H}_{2} \mathrm{~S}$ participates in cell physiology and autophagic pathways in the neuronal cells treated with $\mathrm{NaN}_{3}$.

In the present study, the features of the neuronal damage induced by $\mathrm{NaN}_{3}$ treatment were investigated. Then, the potential neuroprotective activity of $\mathrm{H}_{2} \mathrm{~S}$ and its effect on autophagic cell death were investigated following $\mathrm{NaN}_{3}$ treatment in neuron-like rat pheochromocytoma (PC12) cells. This is the first study demonstrating that $\mathrm{NaN}_{3}$ can induce autophagic cell death in PC12 cells and that $\mathrm{H}_{2} \mathrm{~S}$ can suppress this effect. The present findings may help to gain a better insight into the physiological functions of $\mathrm{H}_{2} \mathrm{~S}$ in the normal and injured conditions and its association with the cellular and molecular mechanisms underlying nervous system lesion and repair.

\section{Materials and methods}

Cell culture. Rat pheochromocytoma PC12 cells were obtained from the Shanghai Institute of Cell Biology, Chinese Academy of Sciences (Shanghai, China). PC12 cells were grown on polystyrene tissue culture dishes in Dulbecco's modified Eagle's medium (DMEM) containing 10\% horse serum (both from Gibco; Thermo Fisher Scientific, Inc., Waltham, MA, USA) and 5\% fetal bovine serum (FBS; Sijiqing Biological Engineering Materials Co., Ltd., Hangzhou, China), supplemented with $2 \mathrm{mmol} / \mathrm{l}$ glutamine, $100 \mu \mathrm{g} / \mathrm{ml}$ streptomycin and $100 \mathrm{U} / \mathrm{ml}$ penicillin (Gibco; Thermo Fisher Scientific, Inc.) at $37^{\circ} \mathrm{C}$ with $95 \%$ air- $5 \% \mathrm{CO}_{2}$. Prior to differentiation, the medium was changed twice a week and the cells were subcultured at a ratio of 1:4 once a week. For differentiation, the cells were washed and incubated in fresh medium containing nerve growth factor (NGF; final concentration of $50 \mathrm{ng} / \mathrm{ml}$ ) for $48 \mathrm{~h}$ at $37^{\circ} \mathrm{C}$ in a cell incubator. The addition and concentration of NGF in the media was maintained throughout all experiments and cell were used between passages 3-8.

Cell injury model. For simulating injury, the DMEM medium was removed, PC12 cells were washed twice with glucose-free Earle's balanced salt solution ( $\mathrm{pH} 7.5$ ), and changed to glucose-free DMEM medium without FBS prior to treatment. Then neurotoxic damage was induced by adding the indicated concentrations of $\mathrm{NaN}_{3}$ for different periods of time in the cultured cells. Cells were preincubated with the indicated concentrations of sodium hydrosulfide (NaHS), as a donor of $\mathrm{H}_{2} \mathrm{~S}$, for 30 min prior to $\mathrm{NaN}_{3}$ treatment and maintained throughout the entire experiment. NaHS was dissolved in saline and was freshly prepared just before use. The stock solutions were directly added into the bath solution to achieve the final concentration. Control cultures were maintained in DMEM medium for the same duration and were left untreated. The concentrations of all reagents were maintained throughout the injury period.
Determination of cell viability. The viability of PC12 cells was determined by Cell Counting Kit-8 (CCK-8) assay (Dojindo Molecular Technologies, Inc., Kumamoto, Japan), according to the manufacturer's instructions. PC12 cells were cultured in 96 -well plates at $37^{\circ} \mathrm{C}$ under an atmosphere of $5 \% \mathrm{CO}_{2}$ and $95 \%$ air. At the end of treatment, CCK- 8 reagent $(10 \mu \mathrm{l})$ was added to each well of the plates and then the plates were incubated at $37^{\circ} \mathrm{C}$ for $3-4 \mathrm{~h}$ in the incubator. Absorbance at a wavelength of $450 \mathrm{~nm}$ was measured with a microplate reader (BioTek Instruments, Inc., Winooski, VT, USA). The mean optical density (OD) of 6 replicate wells in each of the indicated groups were calculated, and the cell viability was expressed as a \% of the control. All experiments were performed in triplicate and repeated three independent times.

Nuclear staining for assessment of cell death. Chromosomal condensation and morphological changes in the nucleus of PC12 cells were observed by DAPI and propidium iodide (PI) staining. The PC12 cells were fixed with $4 \%$ paraformaldehyde for $10 \mathrm{~min}$. Following three rinses with PBS, the cells were stained with $10 \mu \mathrm{g} / \mathrm{ml}$ DAPI for $10 \mathrm{~min}$. PI $(10 \mathrm{mg} / \mathrm{ml}$; Sigma-Aldrich; Merck KGaA, Darmstadt, Germany) was diluted in $0.9 \% \mathrm{NaCl}$ to a working concentration of $40 \mu \mathrm{g} / \mathrm{ml}$. For detection of PI-labeled cells, cells were fixed in $100 \%$ ethanol for $10 \mathrm{~min}$ at room temperature, then were stained with PI for $30 \mathrm{~min}$ at room temperature, washed 3 times in PBS and coverslipped with Permount (Biomeda Corporation, Burlingame, CA, USA), and photographed on a Nikon Eclipse Ti-S fluorescence microscope (Nikon Corporation, Tokyo, Japan) using excitation/emission filters at 568/585 $\mathrm{nm}$ for PI. Viable cells exhibited a normal nucleus size and uniform fluorescence in the DAPI channel, whereas dead cells exhibited PI/DAPI double positive staining and condensed nuclei. Colocalization and morphometric measurements were performed using ImageJ software, version 1.6 (National Institutes of Health, Bethesda, MD, USA). To quantify the immunoreacted cells, the fluorescence intensity was measured in 10 randomly selected images. Data were obtained from at least three independent experiment.

Immunofluorescence analysis. PC12 cells in 24-well plates were fixed with $4 \%$ paraformaldehyde for $15 \mathrm{~min}$ at room temperature and washed thrice with PBS for $10 \mathrm{~min}$. The cells were then blocked with $5 \%$ donkey serum (Gibco; Thermo Fisher Scientific, Inc.) with $0.3 \%$ Triton X-100 and 5\% bovine serum albumin (BSA) for $2 \mathrm{~h}$ at room temperature. Cells were incubated with rabbit polyclonal primary antibodies targeting microtubule-associated protein 1A/1B-light chain 3 (LC3; cat. no. ab48394; 1:100; Abcam, Cambridge, UK) overnight at $4^{\circ} \mathrm{C}$, followed by a mixture of fluorescein isothiocyanate-conjugated secondary antibodies (1:200; cat. no. 131699; Jackson ImmunoResearch Laboratories, Inc., West Grove, PA, USA) for $2 \mathrm{~h}$ at room temperature. Following three washes with PBS for $10 \mathrm{~min}$ each, $40 \mu \mathrm{g} / \mathrm{ml}$ PI was added for $30 \mathrm{~min}$ at room temperature. Following three further washes with PBS for $10 \mathrm{~min}$ each, the coverslips were mounted using Antifade Mounting Medium (Beyotime Institute of Biotechnology, Haimen, China) and observed with an Eclipse Ti-S fluorescence microscope (Nikon Corporation). Colocalization and morphometric measurements were performed using ImageJ software, version 1.6. To 
quantify the immunoreacted cells, the fluorescence intensity was measured in 10 randomly selected images. Data were obtained from at least three independent experiment.

Western blot analysis. The cells were homogenized in lysis buffer (1\% NP-40, $50 \mathrm{mmol} / 1$ Tris PH 7.5, $5 \mathrm{mmol} / \mathrm{l}$ EDTA, $1 \%$ SDS, $1 \%$ sodium deoxycholate, $1 \%$ Triton X-100, $1 \mathrm{mmol} / \mathrm{l}$ phenylmethanesulfonyl fluoride, $10 \mu \mathrm{g} / \mathrm{ml}$ aprotinin, and $1 \mu \mathrm{g} / \mathrm{ml}$ leupeptin) and the lysates were centrifuged at $15,000 \mathrm{x}$ f for $20 \mathrm{~min}$ at $4^{\circ} \mathrm{C}$. Following determination of protein concentration with a Bradford assay (Bio-Rad Laboratories, Inc., Hercules, CA, USA), $50 \mu \mathrm{g}$ of total protein was subjected to $12 \%$ SDS-polyacrylamide gel electrophoresis. The separated proteins were transferred to a polyvinylidene difluoride membrane (EMD Millipore, Billerica, MA, USA) by a transfer apparatus at $90 \mathrm{~V}$ for $1 \mathrm{~h}$. The membrane was then blocked with $5 \%$ non-fat milk for $2 \mathrm{~h}$ at room temperature and incubated overnight at $4{ }^{\circ} \mathrm{C}$ with primary antibody against CBS (1:200; cat. no. sc-67154; Santa Cruz Biotechnology, Inc., Dallas, TX, USA), 3-MST (1:400; cat. no. sc-374326; Santa Cruz Biotechnology, Inc.), LC3 (1:3,000; cat. no. ab48394; Abcam, Cambridge, UK), Beclin-1 (1:500; cat. no. mb0030; Bioworld Technology, Inc., St. Louis Park, MN, USA), sequestosome 1 (also known as P62; 1:1,000; cat. no. ab56416; Abcam), or $\beta$-actin $(1: 10,000$; cat. no. jla20; Merck KGaA). Following incubation with horseradish peroxidase-conjugated secondary antibodies (A0208, A0216; Beyotime Institute of Biotechnology, Haimen, China), protein signals were visualized using an enhanced chemiluminescence (ECL) system (cat. no. 32106; Pierce; Thermo Fisher Scientific, Inc.). For semiquantitative analysis, protein bands detected by ECL were scanned into Adobe Photoshop CS6 (Adobe Systems, Inc., San Jose, CA, USA) and analyzed using ImageJ software, version 1.6.

Statistical analysis. All statistical analyses were conducted with SPSS statistical software version 16.0 (SPSS, Inc., Chicago, IL, USA). Data are expressed as means \pm standard error of the mean. The statistical significance of differences between groups was determined by one-way analysis of variance followed by Tukey's post hoc multiple comparison tests, or Student t-test for two means comparisons. $\mathrm{P}<0.05$ was considered to indicate a statistically significant difference. Each experiment consisted of at least three replicates per condition.

\section{Results}

$\mathrm{NaN}_{3}$ causes cytotoxicity to PCl2 cells. The effect of $\mathrm{NaN}_{3}$ on the viability of PC12 cells was measured by CCK- 8 assay following treatment with a range of concentrations from 5 to $100 \mathrm{mmol} / \mathrm{l}$ and for different durations $(1,3,6,12,18$ and $24 \mathrm{~h})$. As presented in Fig. 1, treatment of PC12 cells with $\mathrm{NaN}_{3}$ for $12 \mathrm{~h}$ at concentrations from 20 to $100 \mathrm{mmol} / \mathrm{l}$ resulted in a concentration-dependent reduction of cell viability. Further analysis demonstrated that the cell survival decrease caused by treatment with $30 \mathrm{mmol} / 1 \mathrm{NaN}_{3}$ was also time-dependent (Fig. 2).

$\mathrm{NaN}_{3}$ induces autophagic cell death in PC12 cells. The cell morphology of the treated PC12 cells was analyzed by PI/DAPI staining in order to evaluate cell death. By phase-contrast

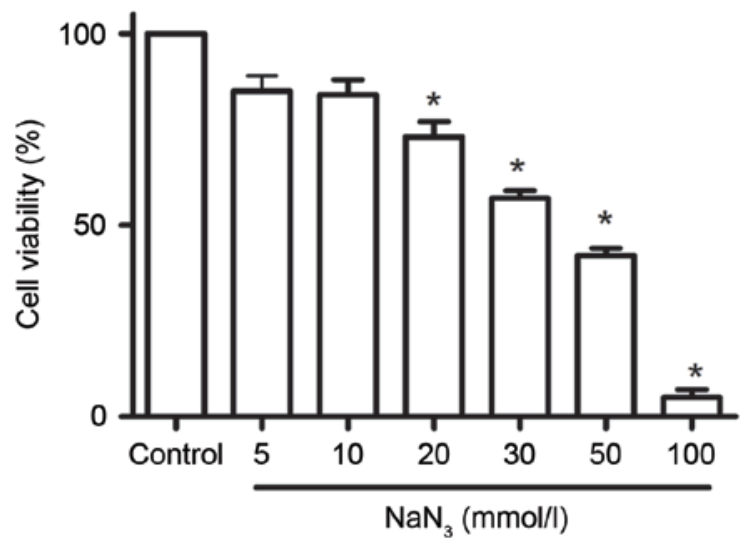

Figure 1. Concentration effect of $\mathrm{NaN}_{3}$ on cell viability in PC12 cells. PC12 cells were treated with $5,10,20,30,50$ or $100 \mathrm{mmol}_{1} \mathrm{NaN}_{3}$ for $12 \mathrm{~h}$ and cell viability was determined by Cell Counting Kit- 8 assay. Data are presented as means \pm standard error of the mean $(n=3)$. ${ }^{*} \mathrm{P}<0.05$ vs. control. $\mathrm{NaN}_{3}$, sodium azide.

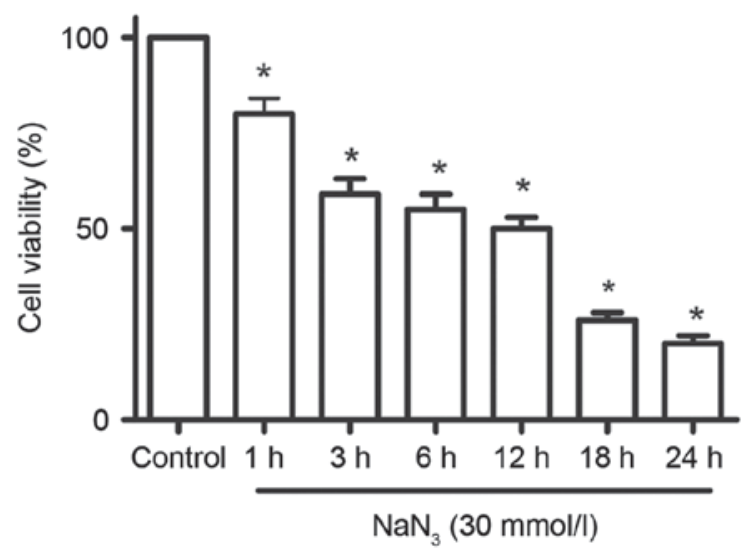

Figure 2. Time effect of $\mathrm{NaN}_{3}$ on cell viability in PC12 cells. PC12 cells were treated with $30 \mathrm{mmol} / 1 \mathrm{NaN}_{3}$ for $1,3,6,12,18$ or $24 \mathrm{~h}$ and cell viability was determined by Cell Counting Kit- 8 assay. Data are presented as means \pm standard error of the mean $(n=3)$. ${ }^{*} \mathrm{P}<0.05$ vs. control. $\mathrm{NaN}_{3}$, sodium azide.

microscopy, PC12 cells treated with $30 \mathrm{mmol} / 1 \mathrm{NaN}_{3}$ for $12 \mathrm{~h}$ appeared more round to oval in shape, compared with the long spindle-like shape of untreated control PC12 cells (Fig. 3A). Following DAPI/PI double staining, the nuclei of control cells appeared round to oval, with a separate pattern of blue fluorescence (DAPI) and red fluorescence (PI). Upon $\mathrm{NaN}_{3}$ treatment, nuclei became increasingly bright, decreased in size, and condensed into round bodies (Fig. 3A). To distinguish which type of cell death was induced by $\mathrm{NaN}_{3}$ treatment, neuronal cultures were examined following staining for PI and for the autophagy marker LC3. The results indicated that LC3/PI double-positive cells existed in both the control and $\mathrm{NaN}_{3}$-injured group (Fig. 3A). Quantification of the microscopy images confirmed that treatment of $\mathrm{PC} 12$ cells with $\mathrm{NaN}_{3}$ resulted in a significant increase in both the number of PI/DAPI-positive cells (Fig. 3B) and the number of PI/LC3 double-positive cells (Fig. 3C), compared with control, suggesting that $\mathrm{NaN}_{3}$ induced autophagic cell death in PC12 cells.

Effect of $\mathrm{NaN}_{3}$ on CBS and 3-MST protein expression in PC12 cells. To examine the expression levels of the endogenous 
A

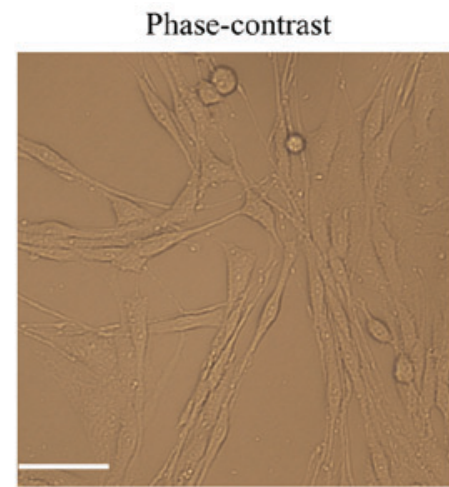

Phase-contrast

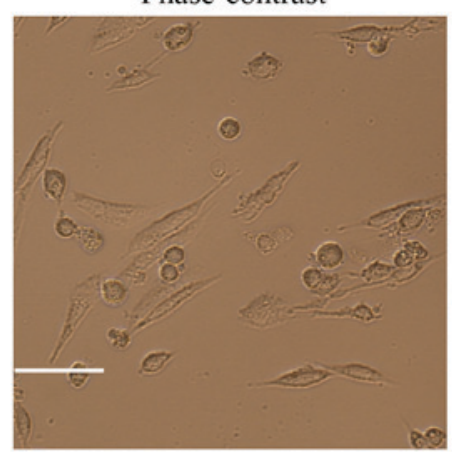

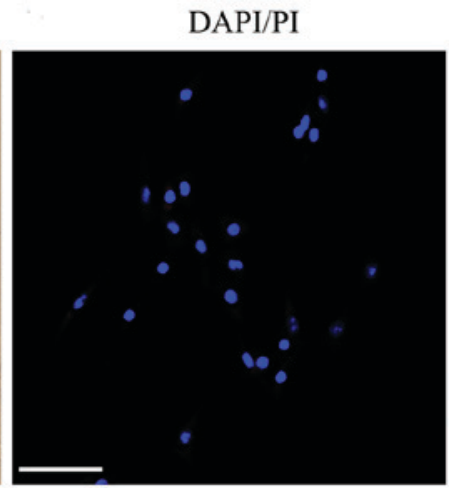

DAPI/PI

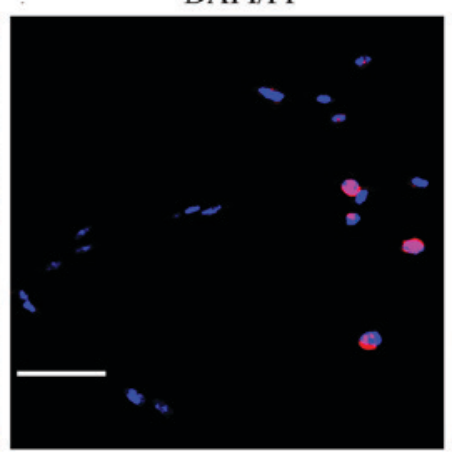

LC3/PI

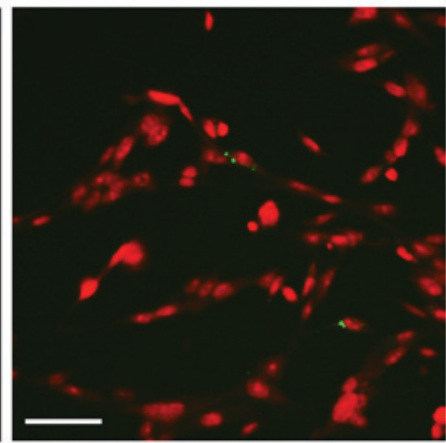

LC3/PI

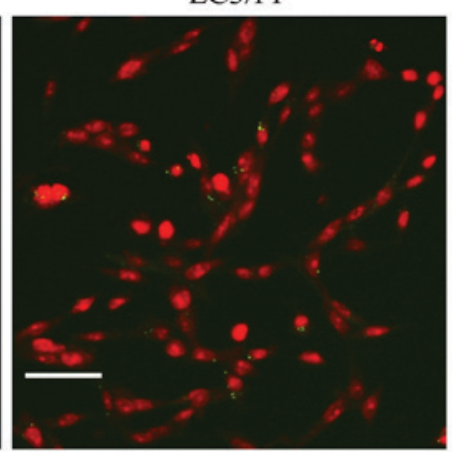

B

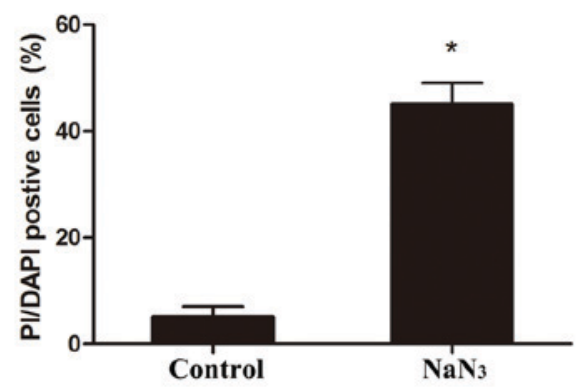

C

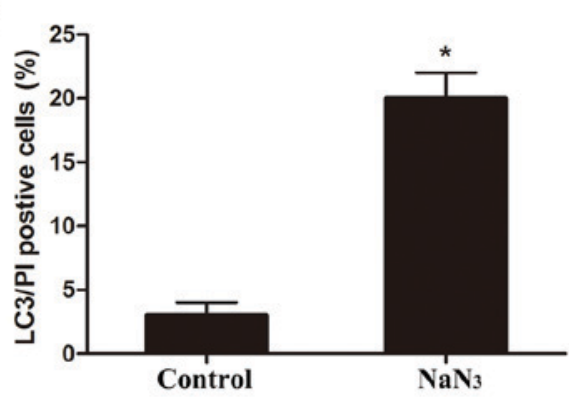

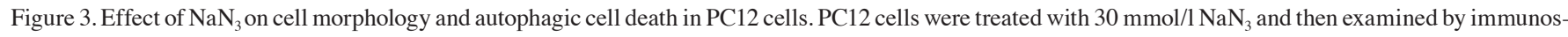
taining and microscopy. Cell death was evaluated by double PI/DAPI staining. Authophagic cell death was evaluated by double LC3/PI staining. (A) Representative images from phase-contrast microscopy and from double-stained fluorescent cells (DAPI, blue; PI, red; LC3, green). Scale bar, $30 \mu \mathrm{m}$. (B) Quantification of the PI/DAPI double-positive cells as \% of total. (C) Quantification of the LC3/PI double-positive cells as \% of total. Data are presented as means \pm standard error of the mean $(\mathrm{n}=3)$. ${ }^{*} \mathrm{P}<0.05$ vs. control. $\mathrm{NaN}_{3}$, sodium azide; PI, propidium iodide; LC3, microtubule-associated protein $1 \mathrm{~A} / 1 \mathrm{~B}-\mathrm{light}$ chain 3 .

$\mathrm{H}_{2} \mathrm{~S}$-producing enzymes, expression of CBS and 3-MST proteins was analyzed by western blotting in control untreated cells and cells treated with different concentrations of $\mathrm{NaN}_{3}$. The expression levels of both CBS and 3-MST proteins decreased in a dose-dependent manner following $\mathrm{NaN}_{3}$ treatment compared with control (Fig. 4).

$\mathrm{H}_{2} \mathrm{~S}$ protects $\mathrm{PC} 12$ cells against $\mathrm{NaN}_{3}$-induced cytotoxicity. To investigate the effect of $\mathrm{H}_{2} \mathrm{~S}$ on $\mathrm{NaN}_{3}$-induced cytotoxicity, cell viability was analyzed by CCK- 8 assay. As illustrated in Fig. 5, treatment with $\mathrm{NaN}_{3}$ at concentrations of $30 \mathrm{mmol} / \mathrm{l}$ for $12 \mathrm{~h}$ significantly attenuated cell viability. The cytotoxic effects of $\mathrm{NaN}_{3}$ on PC12 cells were significantly blocked by pretreatment with 100 and $200 \mu \mathrm{mol} / 1 \mathrm{NaHS}$ for $30 \mathrm{~min}$ (Fig. 5). At $200 \mu \mathrm{mol} / 1, \mathrm{NaHS}$ alone did not affect the viability of PC12 cells (Fig. 5).

$\mathrm{H}_{2} \mathrm{~S}$ suppresses $\mathrm{NaN}_{3}$-induced autophagic cell death in $\mathrm{PCl}$ cells. Next, the effects of $\mathrm{H}_{2} \mathrm{~S}$ on $\mathrm{NaN}_{3}$-induced autophagic cell death were assessed, by examining the protein expression levels of LC3, Beclin-1 and P62 with western blot analysis (Fig. 6A). Treatment of $\mathrm{PC} 12$ cells with $30 \mathrm{mmol} / 1 \mathrm{NaN}_{3}$ for $12 \mathrm{~h}$ significantly increased the protein expression levels of LC3 (Fig. 6B) and Beclin-1 (Fig. 6C), but decreased P62 expression (Fig. 6D) compared with control untreated cells. However, Pretreatment with $200 \mu \mathrm{mol} / 1 \mathrm{NaHS}$ significantly abolished the sodium azide-induced decrease of P62 expression and the increase of LC-3 and Beclin-1 expression (Fig. 6). These results indicated that $\mathrm{H}_{2} \mathrm{~S}$ was able to block the $\mathrm{NaN}_{3}$-elicited downregulation of P62 expression and upregulation of LC 3 and Beclin-1 expression.

The effect of NaHS pretreatment on autophagic cell death in PC12 cells was further examined by LC3/PI double staining and microscopy analysis. As illustrated in Fig. 7, following treatment with $\mathrm{NaN}_{3}(30 \mathrm{mmol} / \mathrm{l}, 12 \mathrm{~h}$ ), the number of LC3/PI double-positive cells significantly increased compared with the control untreated group. Pretreatment with NaHS $(200 \mu \mathrm{mol} / \mathrm{l})$ dramatically ameliorated this $\mathrm{NaN}_{3}$-induced increase of PI/LC3 double-positive cells (Fig. 7), suggesting that $\mathrm{H}_{2} \mathrm{~S}$ 
A

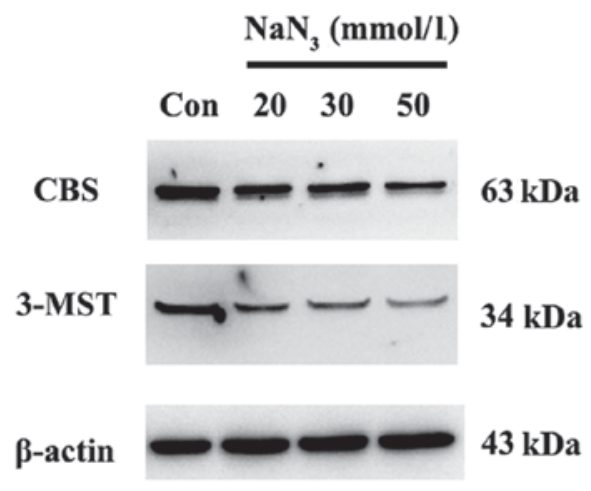

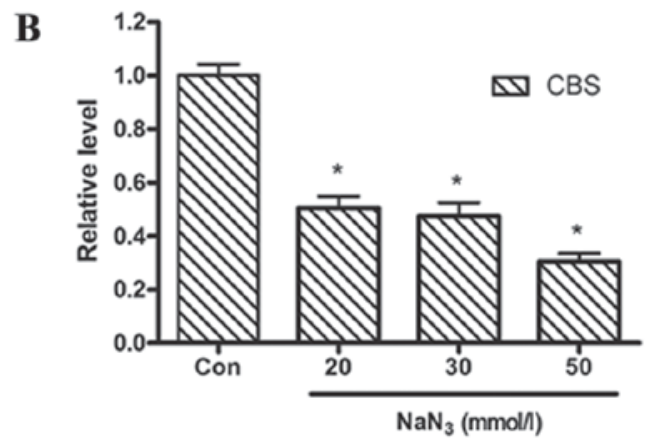

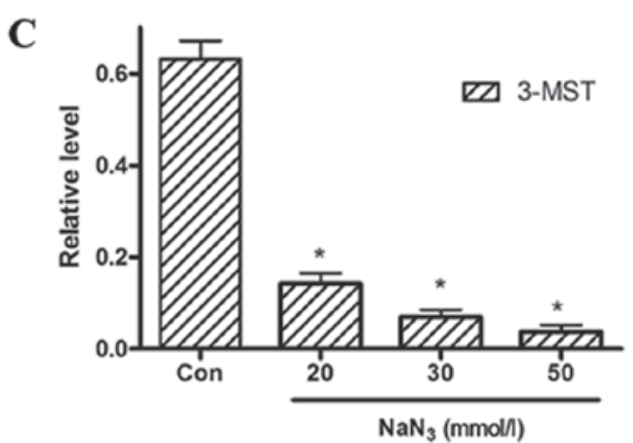

Figure 4. Effect of $\mathrm{NaN}_{3}$ on protein expression of CBS and 3-MST in PC12 cells. Cells were treated with different concentrations of $\mathrm{NaN}_{3}$ for $12 \mathrm{~h}$, and then analyzed by (A) western blotting for CBS and 3-MST. The relative protein expression of (B) CBS and (C) 3-MST was calculated, with $\beta$-actin as the loading control. Representative images and quantification as mean protein levels relative to $\beta$-actin \pm standard error of the mean $(n=3)$. ${ }^{*} \mathrm{P}<0.05$ vs. control. NaN $\mathrm{N}_{3}$, sodium azide; CBS, cystathionine- $\beta$-synthase; 3 -MST, 3 -mercaptopyruvate sulfurtransferase; Con, control.

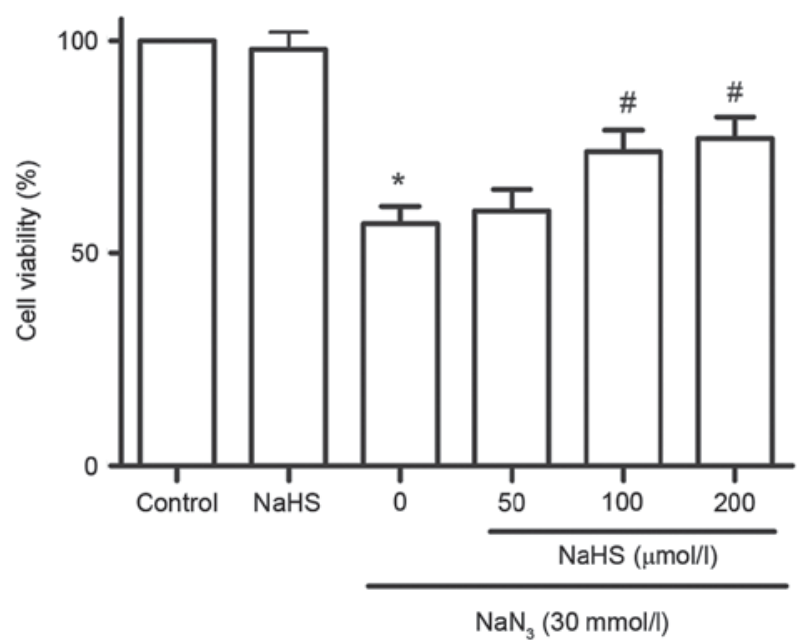

Figure 5. Effect of $\mathrm{H}_{2} \mathrm{~S}$ on $\mathrm{NaN}_{3}$-induced cytotoxicity in PC12 cells. PC12 cells were treated with $\mathrm{NaN}_{3}(30 \mathrm{mmol} / \mathrm{l})$ for $12 \mathrm{~h}$ in the absence or presence of $\mathrm{NaHS}(50,100$ or $200 \mathrm{mmol} / \mathrm{l})$ as a donor for $\mathrm{H}_{2} \mathrm{~S}$, and then cell viability was determined by CCK-8 assay. Data are presented as means \pm standard error of the mean ( $\mathrm{n}=6)$. ${ }^{*} \mathrm{P}<0.05$ vs. control; ${ }^{*} \mathrm{P}<0.05$ vs. $\mathrm{NaN}_{3}$ alone. $\mathrm{H}_{2} \mathrm{~S}$, hydrogen sulfide; $\mathrm{NaN}_{3}$, sodium azide; $\mathrm{NaHS}$, sodium hydrosulfide.

protected the cells from autophagic cell death. The control and NaHS-treated groups displayed few LC3/PI double-positive cells (Fig. 7).

\section{Discussion}

The present study examined the cell damage occurring in cultured PC12 cells exposed to $\mathrm{NaN}_{3}$. Due to the ability of $\mathrm{NaN}_{3}$ to induce cell death through inhibition of the electron transfer between COX and oxygen, this in vitro model represents an interesting tool in neurotoxicity studies. In the present study, the possible molecular mechanisms underlying the neuroprotective effects of $\mathrm{H}_{2} \mathrm{~S}$ to protect against $\mathrm{NaN}_{3}$-induced neuron cell injury were investigated. The results demonstrated a concentration-dependent loss of cell viability induced by $\mathrm{NaN}_{3}$. To explore whether autophagic cell death was induced by $\mathrm{NaN}_{3}$, double immunofluorescence staining was performed for the autophagy marker LC3 and for PI. Microscopy analysis indicated that LC3 positive staining was partly colocalized with PI (a cell death marker), implying that a proportion of dying cells were undergoing autophagy, which is one of the mechanisms of $\mathrm{NaN}_{3}$-induced neurotoxicity. This finding is the first report of $\mathrm{NaN}_{3}$ inducing autophagic cell death in PC12 cells. In addition, exposure of $\mathrm{PC} 12$ cells to $\mathrm{NaN}_{3}$ downregulated the expression of the endogenous $\mathrm{H}_{2} \mathrm{~S}$ synthases (CBS and 3-MST) in a concentration-dependent manner, suggesting that $\mathrm{H}_{2} \mathrm{~S}$ was involved in the pathophysiology of $\mathrm{NaN}_{3}$-induced cell injury. Furthermore, NaHS, a $\mathrm{H}_{2} \mathrm{~S}$ donor was demonstrated to prevent the $\mathrm{NaN}_{3}$-exerted upregulation of $\mathrm{LC} 3$ and Beclin-1 expression and downregulation of P62 expression. A significant reduction in the number of LC3/PI double-positive cells was also observed following pretreatment with NaHS, suggesting that $\mathrm{H}_{2} \mathrm{~S}$ may have yielded a protective effect against $\mathrm{NaN}_{3}$-mediated autophagic cell death. Taken together, the present findings suggest that $\mathrm{H}_{2} \mathrm{~S}$ may be an important protective factor against $\mathrm{NaN}_{3}$-induced neurotoxicity by modulating the autophagic cell death pathway.

$\mathrm{NaN}_{3}$ is a highly reactive white crystalline powder used in industry, which is also used as a preservative in aqueous laboratory reagents and biologic fluids, and as a fuel in automobile airbag gas generates (19). It is also a broad-spectrum biocide 
A

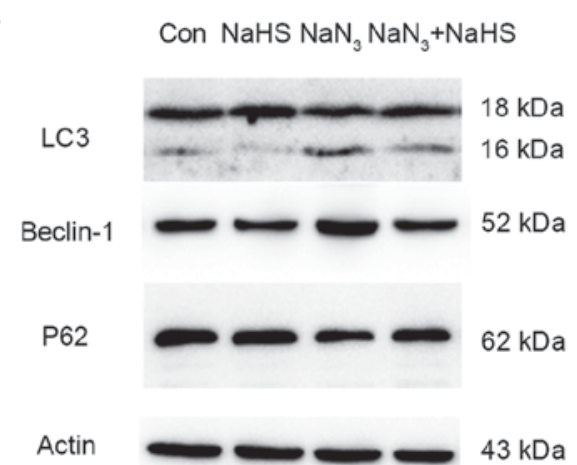

C Beclin-1

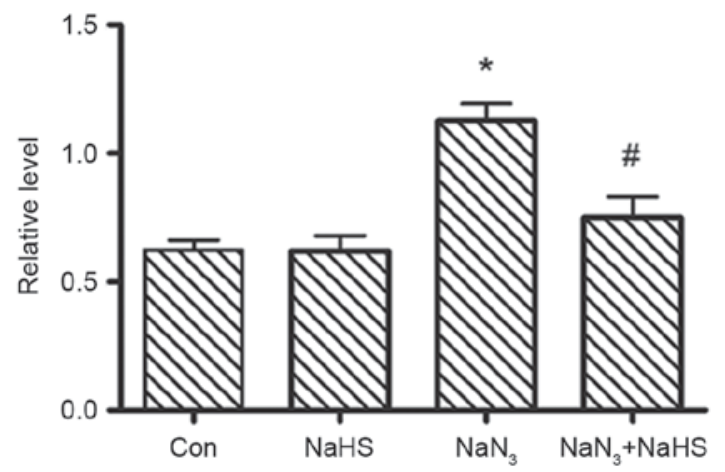

B

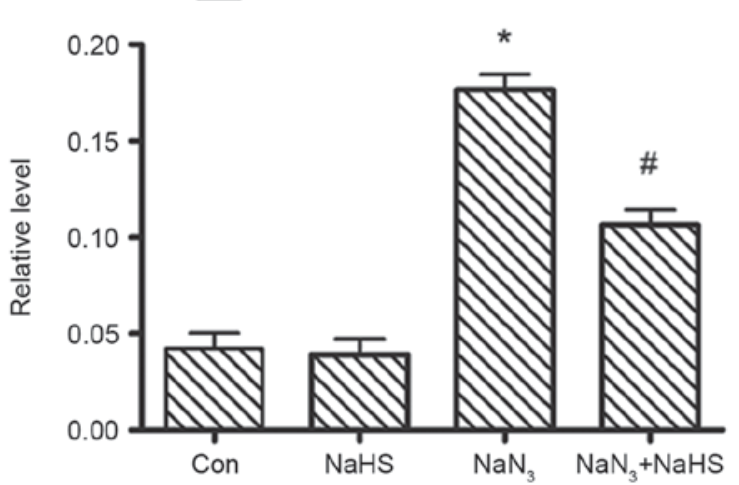

D $\Delta \mathrm{P} 62$

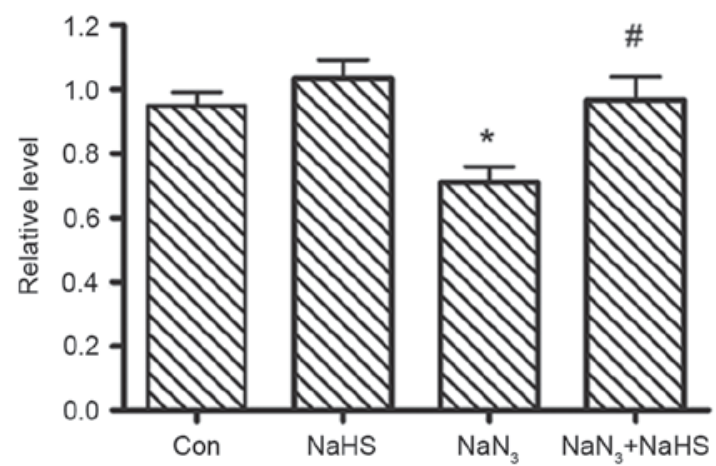

Figure 6. Effect of $\mathrm{H}_{2} \mathrm{~S}$ on $\mathrm{NaN}_{3}$-induced autophagy-related protein expression in PC12 cells. Cells were treated with $\mathrm{NaN}_{3}(30 \mathrm{mmol} / \mathrm{l})$ for $12 \mathrm{~h}$ in the absence or presence of $\mathrm{NaHS}(200 \mathrm{mmol} / \mathrm{l})$ as a donor for $\mathrm{H}_{2} \mathrm{~S}$. Cells were then analyzed for protein expression of LC3, Beclin-1 and P62 by western blotting. (A) Representative images. (B-D) Quantification of protein levels relative to $\beta$-actin. Data are presented as means \pm standard error of the mean (n=3). ${ }^{*} \mathrm{P}<0.05$ vs. control; ${ }^{\prime} \mathrm{P}<0.05$ vs. $\mathrm{NaN}_{3}$ alone. $\mathrm{H}_{2} \mathrm{~S}$, hydrogen sulfide; $\mathrm{NaN}_{3}$, sodium azide; $\mathrm{NaHS}$, sodium hydrosulfide; $\mathrm{LC} 3$, microtubule-associated protein $1 \mathrm{~A} / 1 \mathrm{~B}$-light chain 3; P62, sequestosome 1; Con, control.

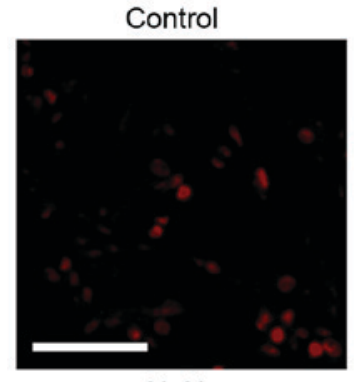

$\mathrm{NaN}_{3}$

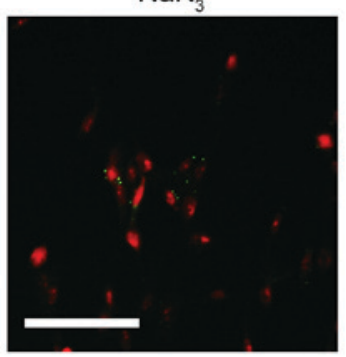

$\mathrm{NaHS}$

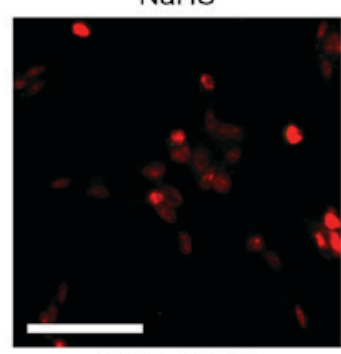

$\mathrm{NaN}_{3}+\mathrm{NaHS}$

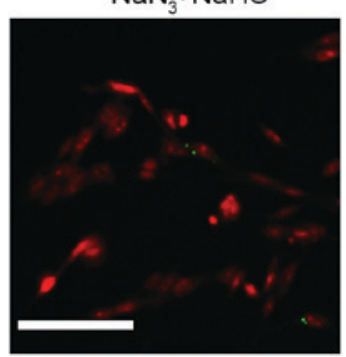

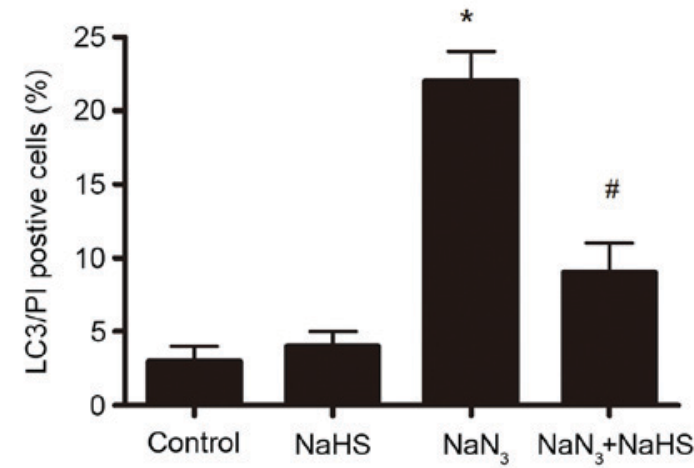

Figure 7. Effect of $\mathrm{H}_{2} \mathrm{~S}$ on $\mathrm{NaN}_{3}$-induced autophagic cell death in PC12 cells. Autophagic cell death in PC12 cells was examined by staining with LC3 (green) and PI (red) and microscopy analysis. Representative images and quantification as mean \% LC3/PI double-positive cells per total \pm standard error of the mean ( $\mathrm{n}=3$ ). Scale bars, $50 \mu \mathrm{m}$. ${ }^{*} \mathrm{P}<0.05$ vs. control; ${ }^{\mathrm{P}}<0.05$ vs. $\mathrm{NaN}_{3}$ alone. $\mathrm{H}_{2} \mathrm{~S}$, hydrogen sulfide; $\mathrm{NaN}_{3}$, sodium azide; LC3, microtubule-associated protein 1A/1B-light chain 3; PI, propidium iodide; NaHS, sodium hydrosulfide.

used in research and agriculture. $\mathrm{NaN}_{3}$, as a COX inhibitor, has been extensively considered as a useful tool to study different pathological conditions. Mitochondrial energy metabolism has been hypothesized to be a determining element to interpret 
impaired neuron function, reduced molecular turnover, and enhanced cell death $(20,21)$. Inhibition of mitochondrial COX has been reported to induce cell death in a variety of cells. Programmed cell death can be classified into apoptosis, necrosis, and autophagic cell death, and emerging evidence suggests that all three may be important modes of cell death in neural stem/progenitor cells (22). Previous studies suggested that $\mathrm{NaN}_{3}$ could induce neuronal apoptosis and necrosis, which was associated with the mitochondrial pathway $(11,13)$. The role of $\mathrm{NaN}_{3}$ in apoptosis and necrosis has been the subject of extensive investigation, however its role in autophagic cell death remains poorly understood (23-25).

PC12 cells, which are generally considered to have neuronal-like characteristics, appear to be more sensitive to $\mathrm{NaN}_{3}$ compared with other neural tumor cell lines. To induce hypoxia/hypoglycemia or oxidative stress, $\mathrm{NaN}_{3}$ concentrations used in PC12 cells range from $1 \mathrm{mM}$ to $10 \mathrm{mM}(26,27)$. In order to induce autophagic cell death, high concentrations of $\mathrm{NaN}_{3}$ were employed in the present study. Increased autophagy is observed in several experimental injury models $(28,29)$. However, it is not known whether the role of autophagy is protective or detrimental in neural cell injury. It is possible that the role of autophagy following cell injury is dependent upon the cell's capacity to respond in relation to the cumulative burden of damaged or dysfunctional macromolecules and organelles. If the increase in autophagic capacity is insufficient, augmenting autophagy would likely be beneficial. The increase in autophagic capacity is in excess, and inhibiting autophagy may be beneficial. Thus, the role of autophagy may be dictated by whether or not it can meet intracellular demands. Examining cell viability is important in order to evaluate if the cells are still physiologically responsive, or if they are likely to be entering cell death. Therefore, in the present study the overall toxic effects of $\mathrm{NaN}_{3}$ were evaluated by monitoring cell viability in PC12 cells following treatment. Under more severe stress conditions (30 mM NaN3), when PC12 cell viability was severely affected, an accumulation of autophagic cell death was observed.

The concept of autophagic cell death was first established based on observations of increased autophagic markers in dying cells (30). LC3, an autophagosomal ortholog of yeast Atg8, is one of the most reliable markers in the study of autophagy induction (7). Beclin-1, the mammalian orthologue of yeast Atg6, has a central role in autophagy (31). More recently, autophagy flux has been assessed in several injury models based on the levels of the autophagic substrate protein P62 (32). P62 is an adaptor protein that directs ubiquitinated cargo to autophagosomes for degradation. As P62 is degraded along with its cargo, when autophagy flux is increased, its protein levels decrease; conversely, when autophagy flux is inhibited, P62 levels increase (33). The present results demonstrated that treatment with $\mathrm{NaN}_{3}$ significantly increased the amount of LC3 and Beclin-1 expression but decreased P62 expression, suggesting that autophagy flux was increased in the $\mathrm{NaN}_{3}$-induced injury in vitro model. To investigate whether an increase in autophagy was beneficial or detrimental, fluorescence microscopy analysis of LC3/PI double staining was performed in PC12 cells. The results indicated that LC3-positive cells were partly colocalized with PI, implying that a proportion of dying cells were undergoing some degree of autophagy. The nuclei of LC3/PI-positive cells appeared round, which is consistent with autophagic cell death, and they were neither shrunken nor fragmented as is observed in apoptotic nuclei, demonstrating that $\mathrm{NaN}_{3}$ could induce autophagic cell death. The present results demonstrated that $\mathrm{NaN}_{3}$ induced autophagic cell death, which is consistent with prior reports that $\mathrm{NaN}_{3}$ induces non-apoptotic cell death (13).

Selvatici et al (13) reported that mitochondrial dysfunction induced by $\mathrm{NaN}_{3}$ provides a common platform for investigating the mechanisms of neuronal injury, useful for screening potential protective agents against neuronal death. $\mathrm{H}_{2} \mathrm{~S}$ has increasingly been recognized as an important signaling molecule of comparable importance to nitric oxide and carbon monoxide in mammalian systems (34). In addition to its function as a signal molecule, $\mathrm{H}_{2} \mathrm{~S}$ also functions as a cytoprotectant in neurons and cardiac muscle (17). The neuroprotective properties of $\mathrm{H}_{2} \mathrm{~S}$ have been the focus of extensive research for decades (35). Previous reports from our group demonstrated that endogenous $\mathrm{H}_{2} \mathrm{~S}$ is involved in neuronal autophagy in TBI mice $(10,36,37)$. Endogenous $\mathrm{H}_{2} \mathrm{~S}$ is generated by three distinct enzymatic pathways mediated by CSE, CBS and 3-MST (18). CBS and 3-MST are expressed in the brain, while CSE is widely located in other organs (38). Miyamoto et al (39) reported that CSE is not expressed in $\mathrm{PC} 12$ cells and that the 3-MST pathway is primarily responsible for $\mathrm{H}_{2} \mathrm{~S}$ production in $\mathrm{PC} 12$ cells. In order to explore whether $\mathrm{H}_{2} \mathrm{~S}$ was involved in $\mathrm{NaN}_{3}$-induced autophagy, the expression of endogenous $\mathrm{H}_{2} \mathrm{~S}$ synthases, CBS and 3-MST, was analyzed by western blotting. Exposure of PC12 cells to $\mathrm{NaN}_{3}$ downregulated the expression of CBS and 3-MST in a concentration-dependent manner, suggesting that $\mathrm{H}_{2} \mathrm{~S}$ may be involved in $\mathrm{NaN}_{3}$-induced cell injury. In addition, pretreatment with $\mathrm{NaHS}$, a donor for $\mathrm{H}_{2} \mathrm{~S}$, reduced the number of LC3/PI double-positive cells, suggesting that $\mathrm{H}_{2} \mathrm{~S}$ may have protective effects against $\mathrm{NaN}_{3}$-mediated autophagic cell death.

The potential neuroprotective mechanism of $\mathrm{H}_{2} \mathrm{~S}$ may be that it reduces oxidative stress. Biochemical studies have demonstrated that $\mathrm{NaN}_{3}$ inhibits $\mathrm{COX}$ and interferes with cellular respiration (40). The mitochondrial respiratory chain is one of the most important sites of reactive oxygen species (ROS) production under physiological and pathological conditions (41). ROS generation is considered as a cause of cell death mediated by mitochondrial electron transport chain inhibitors in dopaminergic neuronal cells (42). Oxidative stress caused by overproduction of ROS is detrimental and one of the etiological factors of many neurologic diseases (43). $\mathrm{H}_{2} \mathrm{~S}$ protects various tissues and organs from oxidative stress and also scavenges $\operatorname{ROS}(18,44,45) . \mathrm{H}_{2} \mathrm{~S}$ also upregulates the transcription of antioxidant genes to exert its cytoprotective effect. The kelch-like ECH associated protein 1 (Keap1)-nuclear factor E2-related factor 2 (Nrf2) pathway is the major regulator of cytoprotective responses to oxidative and electrophilic stress (46). The translocation of Nrf2 to the nucleus has been suggested as a molecular mechanism for the $\mathrm{H}_{2} \mathrm{~S}$-mediated protection $(47,48)$. Further study is necessary to clarify the mechanisms underlying the protective effects of $\mathrm{H}_{2} \mathrm{~S}$ on the Keap1-Nrf2 pathway in a $\mathrm{NaN}_{3}$-induced cell injury model.

Although $\mathrm{H}_{2} \mathrm{~S}$ showed a promising neuroprotective effect in $\mathrm{NaN}_{3}$-mediated cell injury in the present study, further research is underway to identify selective autophagy regulators 
that may serve as potential targets for treatment. In summary, the present results suggested an active role for $\mathrm{H}_{2} \mathrm{~S}$ in the process of autophagy induced by $\mathrm{NaN}_{3}$. This is the first report of autophagic cell death in PC12 cells induced by $\mathrm{NaN}_{3}$. The present data may provide a potential novel pathway to elucidate the underlying molecular and cellular mechanisms of CNS following inhibition of COX and potential novel strategies for the treatment of CNS diseases. Further studies, such as examining other $\mathrm{H}_{2} \mathrm{~S}$ biosynthesis enzymes of the trans-sulfuration pathway, other signal transduction pathways involved in the $\mathrm{H}_{2} \mathrm{~S}$ protective effect, and the functional consequences of $\mathrm{H}_{2} \mathrm{~S}$ on cellular autophagy and its downstream signaling targets, will strengthen these conclusions.

\section{Acknowledgements}

The present study was supported by the National Natural Science Foundation of China (grant nos. 81601306, 81301039, 81530062, 81271379 and 81172911); China Postdoctoral Science Foundation Funded Project (grant no. 2015M570476); the Priority Academic Program Development of Jiangsu Higher Education Institutions (PAPD); Jiangsu Talent Youth Medical Program (grant no. QNRC2016245); Shanghai Key Lab of Forensic Medicine (grant no. KF1502); Key Laboratory of Evidence Science (China University of Political Science and Law), Ministry of Education (grant no. 2016KFKT05); and the Suzhou Science and Technology Development Project (grant no. SYSD2015119).

\section{References}

1. Mittenberg W, DiGiulio DV, Perrin S and Bass AE: Symptoms following mild head injury: Expectation as aetiology. J Neurol Neurosurg Psychiatry 55: 200-204, 1992.

2. Harris LK, Black RT, Golden KM, Reeves TM, Povlishock JT and Phillips LL: Traumatic brain injury-induced changes in gene expression and functional activity of mitochondrial cytochrome C oxidase. J Neurotrauma 18: 993-1009, 2001.

3. Gu YL, Zhang LW, Ma N, Ye LL, Wang de X and Gao X: Cognitive improvement of mice induced by exercise prior to traumatic brain injury is associated with cytochrome c oxidase. Neurosci Lett 570: 86-91, 2014.

4. Huttemann M, Lee I, Kreipke CW and Petrov T: Suppression of the inducible form of nitric oxide synthase prior to traumatic brain injury improves cytochrome c oxidase activity and normalizes cellular energy levels. Neuroscience 151: 148-154, 2008.

5. Bennett MC, Mlady GW, Kwon YH and Rose GM: Chronic in vivo sodium azide infusion induces selective and stable inhibition of cytochrome c oxidase. J Neurochem 66: 2606-2611, 1996.

6. Fayaz SM, Suvanish Kumar VS and Rajanikant GK: Necroptosis: Who knew there were so many interesting ways to die? CNS Neurol Disord Drug Targets 13: 42-51, 2014.

7. Park Y, Liu C, Luo T, Dietrich WD, Bramlett $\mathrm{H}$ and Hu B Chaperone-mediated autophagy after traumatic brain injury. J Neurotrauma 32: 1449-1457, 2015.

8. Cheng G, Kong RH, Zhang LM and Zhang JN: Mitochondria in traumatic brain injury and mitochondrial-targeted multipotential therapeutic strategies. Br J Pharmacol 167: 699-719, 2012.

9. Sarkar C, Zhao Z, Aungst S, Sabirzhanov B, Faden AI and Lipinski MM: Impaired autophagy flux is associated with neuronal cell death after traumatic brain injury. Autophagy 10: 2208-2222, 2014.

10. Zhang M, Shan H, Chang P, Wang T, Dong W, Chen X and Tao L: Hydrogen sulfide offers neuroprotection on traumatic brain injury in parallel with reduced apoptosis and autophagy in mice. PLoS One 9: e87241, 2014.

11. Zhang L, Cheng XR, Hu JJ, Sun L and Du GH: Neuroprotective Effects of hyperoside on sodium azide-induced apoptosis in PC12 cells. Chin J Natural Med 9: 450-455, 2011.
12. Grammatopoulos TN, Morris K, Bachar C, Moore S, Andres R and Weyhenmeyer JA: Angiotensin II attenuates chemical hypoxia-induced caspase- 3 activation in primary cortical neuronal cultures. Brain Res Bull 62: 297-303, 2004.

13. Selvatici R, Previati M, Marino S, Marani L, Falzarano S, Lanzoni I and Siniscalchi A: Sodium azide induced neuronal damage in vitro: Evidence for non-apoptotic cell death. Neurochem Res 34: 909-916, 2009.

14. Huang CW and Moore PK: H2S synthesizing enzymes: Biochemistry and molecular aspects. Handb Exp Pharmacol 230: 3-25, 2015.

15. Bhatia M: Role of hydrogen sulfide in the pathology of inflammation. Scientifica (Cairo) 2012: 159680, 2012.

16. Kimura H: Hydrogen sulfide and polysulfides as biological mediators. Molecules 19: 16146-16157, 2014.

17. Kimura H: Hydrogen sulfide: Its production, release and functions. Amino Acids 41: 113-121, 2011.

18. Kimura H: Physiological roles of hydrogen sulfide and polysulfides. Handb Exp Pharmacol 230: 61-81, 2015.

19. Chang S and Lamm SH: Human health effects of sodium azide exposure: A literature review and analysis. Int $\mathbf{J}$ Toxicol 22: 175-186, 2003.

20. Ott M, Gogvadze V, Orrenius S and Zhivotovsky B: Mitochondria, oxidative stress and cell death. Apoptosis 12: 913-922, 2007.

21. Yin F, Boveris A and Cadenas E: Mitochondrial energy metabolism and redox signaling in brain aging and neurodegeneration. Antioxid Redox Signal 20: 353-371, 2014.

22. Ryu JR, Hong CJ, Kim JY, Kim EK, Sun W and Yu SW: Control of adult neurogenesis by programmed cell death in the mammalian brain. Mol Brain 9: 43, 2016.

23. Sato E, Suzuki T, Hoshi N, Sugino T and Hasegawa H: Sodium azide induces necrotic cell death in rat squamous cell carcinoma SCC131. Med Mol Morphol 41: 211-220, 2008.

24. Inomata $\mathrm{K}$ and Tanaka $\mathrm{H}$ : Protective effect of benidipine against sodium azide-induced cell death in cultured neonatal rat cardiac myocytes. J Pharmacol Sci 93: 163-170, 2003.

25. Lutton JD, Moonga BS and Dempster DW: Osteoclast demise in the rat: Physiological versus degenerative cell death. Exp Physiol 81: 251-260, 1996

26. Amador FC, Henriques AG, da Cruz E Silva OA and da Cruz E Silva EF: Monitoring protein phosphatase 1 isoform levels as a marker for cellular stress. Neurotoxicol Teratol 26: 387-395, 2004.

27. Satpute R, Bhattacharya R, S Kashyap R, J Purohit H, Y Deopujari J, M Taori G and F Daginawala H: Antioxidant potential of Fagonia arabica against the chemical ischemia-induced in PC12 cells. Iran J Pharm Res 11: 303-313, 2012.

28. Smith CM, Chen Y, Sullivan ML, Kochanek PM and Clark RS: Autophagy in acute brain injury: Feast, famine, or folly? Neurobiol Dis 43: 52-59, 2011.

29. Liu L, Sun T, Xin F, Cui W, Guo J and Hu J: Nerve growth factor protects against alcohol-induced neurotoxicity in PC12 cells via PI3K/Akt/mTOR pathway. Alcohol Alcohol 52: 12-18, 2017.

30. Shen HM and Codogno P: Autophagic cell death: Loch Ness monster or endangered species? Autophagy 7: 457-465, 2011.

31. Kang R, Zeh HJ, Lotze MT and Tang D: The Beclin 1 network regulates autophagy and apoptosis. Cell Death Differ 18: 571-580, 2011.

32. Klionsky DJ, Abdalla FC, Abeliovich H, Abraham RT, AcevedoArozena A, Adeli K, Agholme L, Agnello M, Agostinis P, Aguirre-Ghiso JA, et al: Guidelines for the use and interpretation of assays for monitoring autophagy. Autophagy 8: 445-544, 2012.

33. Lipinski MM, Wu J, Faden AI and Sarkar C: Function and mechanisms of autophagy in brain and spinal cord trauma. Antioxid Redox Signal 23: 565-577, 2015.

34. Gotor C, Garcia I, Crespo JL and Romero LC: Sulfide as a signaling molecule in autophagy. Autophagy 9: 609-611, 2013.

35. Kimura H: Hydrogen sulfide: Production, release, and functions. Nihon Yakurigaku Zasshi 139: 6-8, 2012 (In Japanese).

36. Zhang M, Shan H, Chang P, Ma L, Chu Y, Shen X, Wu Q, Wang Z, Luo C, Wang T, et al: Upregulation of 3-MST relates to neuronal autophagy after traumatic brain injury in mice. Cell Mol Neurobiol 37: 291-302, 2017.

37. Zhang M, Shan H, Wang Y, Wang T, Liu W, Wang L, Zhang L, Chang P, Dong W, Chen X and Tao L: The expression changes of cystathionine-b-synthase in brain cortex after traumatic brain injury. J Mol Neurosci 51: 57-67, 2013.

38. Chen WL, Niu YY, Jiang WZ, Tang HL, Zhang C, Xia QM and Tang XQ: Neuroprotective effects of hydrogen sulfide and the underlying signaling pathways. Rev Neurosci 26: 129-142, 2015. 
39. Miyamoto R, Otsuguro K, Yamaguchi S and Ito S: Contribution of cysteine aminotransferase and mercaptopyruvate sulfurtransferase to hydrogen sulfide production in peripheral neurons. J Neurochem 130: 29-40, 2014.

40. Zhang ZY, Chen B, Zhao DJ and Kang L: Functional modulation of mitochondrial cytochrome c oxidase underlies adaptation to high-altitude hypoxia in a Tibetan migratory locust. Proc Biol Sci 280: 20122758, 2013

41. Sena LA and Chandel NS: Physiological roles of mitochondrial reactive oxygen species. Mol Cell 48: 158-167, 2012.

42. Han M and Im DS: Effects of mitochondrial inhibitors on cell viability in U937 monocytes under glucose deprivation. Arch Pharm Res 31: 749-757, 2008.

43. Nagpure BV and Bian JS: Brain, learning, and memory: Role of $\mathrm{H} 2 \mathrm{~S}$ in neurodegenerative diseases. Handb Exp Pharmacol 230: 193-215, 2015.

44. Whiteman M, Armstrong JS, Chu SH, Jia-Ling S, Wong BS, Cheung NS, Halliwell B and Moore PK: The novel neuromodulator hydrogen sulfide: An endogenous peroxynitrite 'scavenger'? J Neurochem 90: 765-768, 2004.
45. Kimura Y, Goto Y and Kimura H: Hydrogen sulfide increases glutathione production and suppresses oxidative stress in mitochondria. Antioxid Redox Signal 12: 1-13, 2010.

46. Kansanen E, Kuosmanen SM, Leinonen H and Levonen AL: The Keap1-Nrf2 pathway: Mechanisms of activation and dysregulation in cancer. Redox Biol 1: 45-49, 2013.

47. Calvert JW, Jha S, Gundewar S, Elrod JW, Ramachandran A, Pattillo CB, Kevil CG and Lefer DJ: Hydrogen sulfide mediates cardioprotection through Nrf2 signaling. Circ Res 105: 365-374, 2009.

48. Liu J, Wu J, Sun A, Sun Y, Yu X, Liu N, Dong S, Yang F, Zhang L, Zhong X, et al: Hydrogen sulfide decreases high glucose/palmitate-induced autophagy in endothelial cells by the Nrf2-ROS-AMPK signaling pathway. Cell Biosci 6: 33, 2016. 